\title{
Effect of Apportioned Federal Revenue on Economic Growth: The Nigerian Experience
}

\author{
Cordelia Onyinyechi Omodero ${ }^{1}$ \\ ${ }^{1}$ Department of Accounting, College of Management Sciences, Michael Okpara University of Agriculture, Umudike, \\ Umuahia, Abia State, Nigeria \\ Correspondence: Cordelia Onyinyechi Omodero, Department of Accounting, College of Management Sciences, \\ Michael Okpara University of Agriculture, Umudike, Umuahia, Abia State, Nigeria.
}

Received: June 4, 2019

Accepted: July 23, 2019

Online Published: July 24, 2019

doi:10.5430/ijfr.v10n4p172

URL: https://doi.org/10.5430/ijfr.v10n4p172

\begin{abstract}
The major objective of income distribution to the federal, state and local governments in Nigeria is to achieve economic growth which leads to economic development. This ultimate aim of governance in Nigeria appears not to have been achieved due to alleged corruption and mismanagement of the monthly allocated funds. Thus, this study investigates the effect of revenue apportioned to the three levels of government on economic growth in Nigeria. The study employs annual time series data which cover a period from 1981-2016 and have been collected from CBN Statistical Bulletin, 2016 edition. Ordinary Least Square (OLS) method is used to perform the multi-regression analysis with the aid of e-views version 9 . The findings of the study reveal that the federally apportioned revenue to the federal government (FAFG) has a significant positive impact on RGDP while FALG has a robust significant positive impact on RGDP. The result also indicates that FASG has a significant negative influence on RGDP. This leads to a conclusion that mismanagement of funds by the state governments is a cause for concern. Therefore, the study suggests, among others, that revenue sharing formula in the country should be based more on impact of expenditure incurred on executed projects (long term and short term) by each tier of government than on any other parameter to achieve fairness and efficiency in public service delivery at all levels of governance.
\end{abstract}

Keywords: federation account, revenue, allocation, economic growth, three tiers of government

JEL Classification: JEL CODE: H71, H77, H79

\section{Introduction}

The federation account is an exceptional account that is required to be maintained by the federation of Nigeria as specified by section 162(1) of the 1999 constitution. All government proceeds in Nigeria are lodged into this account excluding the revenues from the Nigerian Armed Forces, Police Force, Foreign Service Officers and Federal Capital Territory (FCT) Residents. The constitution states that proceed from the Armed Forces, Police Force, Foreign Affairs officers and FCT residents should be paid into the Consolidated Revenue Account (CRF) (Adams, 2006; Ohiomu \& Oluyemi, 2017).

The official revenue allocation formula is used to apportion resources from the federation account to the three levels (federal, state and local governments) of government in Nigeria (ATSWA, 2009). It is also described as a distributable pool account whereby funds are allotted to the federal government, state governments and the local government councils by the Federation Account Allocation Committee on a monthly basis, based on the prevailing revenue sharing formula in the country (Ani \& Obara, 2002). However, realization of economic growth in all parts and facets of the Nigerian economy has been the focus and the underlying reasons behind revenue apportionment in Nigeria.

It is believed that economic growth is a major determinant and pointer of an economy that is robust in all ramifications. A strong economy is characterized by progress in the national income, availability of jobs and enhancement of people's wellbeing (Prateek, 2017). The growth of the ratio of GDP to population (GDP Per Capita), which is also called Per Capita Income is the most important aspect of economic growth (Sciencedaily, 2018). As the country's GDP is increasing, it becomes productive and leads to more people being employed. This increases the wealth of the country and its population. 
According to Prateek (2017), the six factors that drive economic growth in a country include: discovery of natural resources, infrastructure, availability of workers, and investment in human capital, technological advancement and laws to regulate economic activities. In the same manner, poor health and low levels of education, inadequate infrastructures, capital flight, political instability, lack of proper institutional framework are major constraints to economic growth (Prateek. 2017). In Nigeria, economic growth and development are the underlying reasons for revenue allocation to the three tiers of government from an account called federation account.

The federation account was established by law so that revenue allotment to the three organs of government in Nigeria will be done in accordance with the legal framework in the country following the constitutionally acceptable ratios. The Federation Account Allocation Committee (FAAC) carries out the responsibility of fund allocation in the country. The committee comprises the Chairman which is the Minister for Finance, Accountant General of the Federation, Commissioners of Finance of the 36 states of the federation and representatives of other institutions such as the Central Bank of Nigeria, Nigerian National Petroleum Corporation (NNPC), Federal Inland Revenue Service (FIRS), Customs, National Pension Commission, Debt Management Office (DMO), and they usually meet on a monthly basis to deliberate on the allocation of funds.

The Revenue Mobilization and Fiscal Commission (RMAFC) is another commission established by Decree No. 49 of 1989 to ensure equitability and fairness in the fund apportionment to the three tiers of government in the country. The Revenue Mobilization Allocation and Fiscal Commission (RMAFC) established in 1989 have the constitutional backing and obligation to guarantee transparency, correctness and unbiased sharing of revenue in Nigeria.

Revenues that flow into the federation account can be classified into oil and non-oil revenue. Under the oil revenue, we have: Oil pipeline license fees; Royalty on extraction of oil; Rent of oil well and grounds; Sale of petroleum and gas; Penalty for gas flaring. The non-oil revenue includes: personal income tax; companies income tax; capital gains tax; withholding tax and all for forms of indirect taxes (ATSWA, 2009). From the oil revenue, derivation allowance is given to the Niger Delta States as a way of compensating them for the environmental degradation and pollution suffered as a result of oil exploration in their area (Omodero, Ekwe \& Ihendinihu, 2018). This derivation allowance also applies to all States with solid minerals that generate income to the Federal Government (Adangor, 2015).

The problem of the study is the misuse of resources in Nigeria which has made economic development to be on a slow pace. For the period of 36 years which the research examined, revenue allocations to the federal, state and local governments have been (N72,120.01, N20,270.72, N10,357.03 respectively) all in Billions, while the derivation allowance stood at N12,415.84 Billion (CBN Statistical Bulletin, 2016). The major aim of the huge revenue allocation is to boost sustainable economic development across the 36 states of the federation including the Federal Capital Territory (FCT) Abuja and the 774 local governments in the country, but the goal is defeated due to corruption and mismanagement of funds.

\subsection{Objectives of the Study}

The general objective of this study is to determine the impact of the Federation Account allocated Funds on Nigeria's economic growth.

The study also seeks to pursue the following specific objectives:

1. To establish the impact of Federation Account Allocated Fund to the Federal Government (FAFG) on RGDP.

2. To assess the implication of Federation Account Allocated Fund to the State Governments (FASG) on RGDP.

3. To determine the impact of the Federation Account Allocated Fund to the Local Governments (FALG) on RGDP.

\subsection{Research Hypotheses}

To pursue the above study objectives, the following null hypotheses have been formulated:

$\mathrm{Ho}_{1}$ : Federation Account Allocated Fund to the Federal Government does not have significant Impact on RGDP in Nigeria.

$\mathrm{Ho}_{2}$ : Federation Account Allocated Fund to the State Governments does not significantly Influence RGDP in Nigeria.

$\mathrm{Ho}_{3}$ : Federation Account Allocated Fund to the Local Governments does not significantly affect RGDP in Nigeria. 


\section{Theoretical Review}

\subsection{Endogenous Growth Theory}

This research focuses on revenue allocation and its impact on economic growth, thus the study anchors on Endogenous growth theory. Endogenous growth theory is the new growth theory initiated in the early 1980s (Akanbi $\&$ Du Toit, 2011). The theory states that economic growth depends on investment in human capital, innovation and knowledge management (Romer, 1994). The classical, neoclassical and the Keynesian economists were the first to develop economic growth theory. For instance, Solow's model which revealed how the long run rate of growth is exogenously influenced by the rate of technical progress (Solow, 1956). On the other hand, Harrod (1939) and Domar $(1946,1957)$ established the Harrod-Domar model which holds that long run rate is exogenously determined by the savings rate in an economy. All these have one limitation or the other because the savings rate and the rate of technical progress could not be expounded. Endogenous growth theory tries to go beyond these limitations to establish that long run economic growth primarily depends on policy measures within an economy.

The policy measures mentioned here include revenue allocations which positively impact on the long-run economic growth that reflects as increase in real GDP (Dagwom, 2013). The implication is that policies that embrace openness, competition, change and innovation will promote economic growth (Fadare, 2010). The theory also focuses on positive externalities and spillover effects of a knowledge based economy which leads to economic development. Policy effects emanating from this model are connected to the potential for externalities spillovers coming from the wealth of knowledge and perhaps labor force skills. Economies, which have abundance in those factors, can grow faster than the ones limited by their unavailability. By examining policy, the most essential ways to foster growth is to enhance the educational levels of the labor force. Thus, based on this model, education, as a positive spillover, is crucial to growth. Since many developing countries have constraints regarding education and related issues, it is key for governments in those countries trying to prioritize improvements on education and provide subsidies for research and development (Augusto, Raimundo, \& Fontenele, 2012).

Government spending on education (research and development), infrastructures, power and capacity building - which are the product of revenue allocation - is very essential for economic development. It helps to access a common pool of knowledge emanating from global technological spillovers. Technology is a non-rival idea and contagious. Its use by one country does not prevent other countries from benefiting from it. This is why endogenous growth theory stresses on policy measures within an economy as a criterion for economic growth.

Fiscal policy sees government spending on public goods and services as a tool for economic development, but if reverse is the case, that is government spending on things that have negative externalities, then the economic growth will be hampered (William \& Serigo, 1993). An endogenous growth models provide mechanisms through which changes in economic policies and accumulation of human and private physical capital stocks can generate sustained economic growth, even in the absence of exogenous technological change and population growth. The study conducted on Cameroon shows evidence that economic growth is influenced by economic policies. In that study, increases in the budget deficit are found to adversely impact on economic growth (Dhaneshwar, 1997). Scholars that applied this theory in their various studies posit that policy measure such as revenue allocation positively influences economic growth which is reflected in increase in real GDP in the long run (Akanbi \& Du Toit, 2011; Dagwom, 2013).

\subsection{Empirical Review}

Omodero et al. (2018) considered the impact of derivation allowance given to the Niger Delta States on economic development of Nigeria using data that spanned from 1981-2016 and applying ordinary least squares technique for analysis. The study took into account the clamoring of the people in the Niger Delta States for lack of development and the deplorable condition of public facilities in the region. However, the study found evidence that the derivation allowance the states had collected within the period covered by the study impacted positively and significantly on the real gross domestic product (RGDP). In other words, if the derivation fund is well managed, it is capable of effecting development and growth in the Niger Delta States and in the country at large.

Ohiomu and Oluyemi (2017) employed Co-integration and Error Correction Model to examine the impact of fiscal federalism on economic growth in Nigeria, using annual time series data which spanned from 1984-2015. The study used RGDP as the response variable while the funds allotted to the three organs of government were the explanatory variables. The result of the study revealed that revenue allocation to state government increases economic growth by $0.26 \%$ which shows a positive effect on economic growth. In other words revenue allocation to state governments contributed to economic growth in Nigeria. Revenue allocation to federal government showed a minute increase of 
$0.001 \%$ to the economic growth despite the lion share given to it for national projects and general economic development. The result on the allocation to the local government revealed a negative effect of $-0.03 \%$. The study suggested an appraisal of the existing income sharing method which should be centered on the spending functions allocated to every organ of the government in the country.

Ojide and Ogbodo (2015) carried out a study on the federation account allocation in Nigeria and its implication for economic growth from 1970 to 2009. Distributed lag model was used to analyze the relationship between allocations (federal and state governments) and economic growth. The regression result showed that the federal government allocation share and the state governments' internally generated revenue (O.55\% and $0.17 \%$ respectively) have positive and significant association with economic growth, while the state governments' allocation share has a negative and significant relationship with growth $(-0.64 \%)$.

Dagwom (2013) extended the study from 1993 to 2012 and found that revenue allocation to the federal government has a $0.06 \%$ impact on economic growth while the revenue allocation to the local governments increases economic growth by $0.34 \%$ which is far higher than that of the federal government. The result of the revenue allocation to the state government showed negative effect of $-0.13 \%$ on economic growth.

Gemmell, Kneller and Sanz (2013) examined the effect of expenditure and revenue fiscal decentralization indicators on economic growth of 23 Organization for Economic Co-operation and Development (OECD) Countries using a panel data from 1972 to 2005. The study employed Pooled Mean Group (PMG) estimating equation which allows for varied short-run effects across countries but uniform long-run effects. The result of the study revealed that spending decentralization has lower economic growth while the revenue decentralization resulted in a higher growth.

Faridi (2011) used Ordinary Least squares to investigate the impact of fiscal decentralization on economic growth in Pakistan from 1972-2009 and found that both revenue and expenditures fiscal decentralization had positive correlation with economic growth in Pakistan.

Usman (2011) studies the impact of revenue allocation formula on economic growth in Nigeria from 1960-2010 using ordinary least squares technique and found that local and federal governments share of allocation contributed significantly to economic growth while the state government did not meet the economic expectation but exerted negative impact on growth.

\subsection{Research Gap}

This current study addressed the impact of effective utilization of federation account allocated funds to the three tiers of government with emphasis on enhancing economic growth in Nigeria. Some of the previous studies examined in this study stopped at 2015. For instance, Usman (2011) covered a period from 1960-2010, Dagwom (2013) spanned from 1993-2012, Ojide \& Ogbodo covered from 1970-2009 while Ohiomu \& Oluyemi (2017) extended it from 1984-2015 and did not focus on revenue utilization for economic growth enhancement. Omodero et al. (2018) covered the same period but focused on derivation fund enjoyed by the Niger Delta States of Nigeria. This study has improved the growth of empirical literatures in this area of research from 1981 to 2016 which will be useful for researchers and policy makers in the future.

\section{Methodology}

The study made use of ex-post facto and descriptive research designs. Ex-post facto implies after event, thus, the reason for its adoption is the historical nature of the research data which were all in existence as at the time of this study. The descriptive research design allows numerical collection the data and to statistically evaluate them to arrive at the results which could serve as an empirical evidence in this field of study. All data on real gross domestic product, revenue allocation to the federal, state and local governments were gathered from CBN Statistical Bulletin, 2016 edition. The study made use of Augmented Dickey Fuller Unit root testing to establish stationarity of data to avoid spurious regression result. Gordon (1996) submits that economic time series data are usually non-stationary and can only become stationary at the first difference level or even at a higher level which may sometimes involve the use of log. The significance of unit root test is to circumvent misleading estimation result. Ordinary Least Squares (OLS) method was used to perform the multi-regression analysis with the aid of e-views version 9. The choice of OLS was based on the fact that its computation is relatively simple and it possesses some optimal properties. OLS is a regression technique that has been successfully applied and found very appropriate in similar researches like (Okafor, 2012; Syed, Yasir \& Farhan, 2012; Ihenyen \& Mieseigha, 2014; Ojong, Ogar \& Arikpo, 2016; Arowoshegbe, Uniamikogbo \& Aigienohuwa, 2017) among others. This is due to its unique features such as linearity, efficiency, sufficiency, least variances, unbiasedness and least mean errors (Arowoshegbe et al., 2017). 
Koutsoyiannis (1977) model states that economic theory does not indicate the functional form of any relationship. This connotes that a functional relationship may be linear, cubic or even in a quadratic form (Arowoshegbe et al., 2017). For the purpose of this study, the model below was adopted with modifications from Dagwom (2013); Ojide \& Ogbodo (2015); Ohiomu \& Oluyemi (2017) and Usman (2011).

$\mathrm{RGDP}=\mathrm{f}(\mathrm{FAFG}, \mathrm{FASG}, \mathrm{FALG})$

It is expressed in its explicit form as follows:

$$
\mathrm{Y}=\propto+\beta 1 X 1+\beta 2 X 2+\beta 3 X 3+\mu \mathrm{i}
$$

Where:

Y= RGDP (Real Gross Domestic Product)

$\mathrm{X}=$ Determinant of economic development

$\mathrm{X} 1=\mathrm{FAFG}$ (Federal Government Share of fund from the Federation Account)

$\mathrm{X} 2=$ FASG (State Government Share of fund from the Federation Account))

$\mathrm{X} 3=$ FALG (Local Government Share of fund from the Federation Account))

$\beta 1-\beta 3=$ Regression coefficients

$\mu \mathrm{i}=$ Error term.

The A prior expectation is that the fund allocation used by the three tiers of government should be greater than zero implying positive contribution to economic growth in Nigeria.

\section{Data Analysis and Interpretation}

Table 1. Descriptive statistics for FAA and RGDP

\begin{tabular}{lllll}
\hline & RGDP & LOGFAFG & FASG & FALG \\
\hline Mean & 31757.15 & 5.925880 & 563.0756 & 287.6953 \\
\hline Median & 22391.14 & 5.953927 & 84.86500 & 37.23500 \\
\hline Maximum & 69023.93 & 8.928023 & 2122.920 & 1125.080 \\
\hline Minimum & 13779.26 & 2.282382 & 2.720000 & 0.000000 \\
\hline Std.Dev. & 18151.71 & 2.390014 & 707.0765 & 372.0361 \\
\hline Skewness & 0.874864 & -0.219547 & 0.956978 & 0.968926 \\
\hline Kurtosis & 2.318378 & 1.525501 & 2.503586 & 2.523030 \\
\hline Jarque-Bera & 5.289230 & 3.550428 & 5.864482 & 5.974160 \\
\hline Probability & 0.071033 & 0.169447 & 0.053278 & 0.050435 \\
\hline Sum & 1143257. & 213.3317 & 20270.72 & 10357.03 \\
\hline SumSq.Dev. & $1.15 \mathrm{E}+10$ & 199.9258 & 17498500 & 4844380. \\
\hline Observations & 36 & 36 & 36 & 36 \\
\hline
\end{tabular}

Source: Researcher's calculation, 2018 using e-views, version 9.

Table 1 displays the mean values of the variables as well as the standard deviation, skewness and kurtosis. For the purpose of this study, the mean represents the average of the data used in the distribution while the standard deviation is the measure of dispersion of a set of data from its mean. Standard deviation helps to assess how far the values are spread above and below the mean. From Table 1 above, all data for the predictor variables are spread above the mean with exception of the FAFG which has a spread lower than the mean. The response variable (RGDP) has a lower spread which means that FAFG and RGDP are crowded around the mean.

Skewness is used to study the degree and trend of departure from equilibrium. In a symmetrical distribution, the value of mean, median and mode are exactly equal. While in an asymmetrical distribution, the values of mean, median and mode are not equal. When the value of mean, median and mode are equal, there is no skewness. If 
skewness is 0 , it implies that the data are perfectly symmetrical, which is impossible for real-world data. The general rule is that, if the result of the computation is greater than zero, but not above 0.5 , the distribution is positively and approximately skewed. If it is between 0.5 and 1 , the distribution is moderately and positively skewed, but if it is greater than 1 , the distribution is highly and positively skewed. If it is equal to zero, it is symmetric. When the result is less than zero, it is negatively skewed.

The Skewness on Table 1 above indicates that RGDP, FASG and FALG distribution are positively and moderately skewed while FAFG is negatively skewed. The implication is that there could be frequent small negative outcomes but that extremely bad scenarios are not likely to occur but not with FAFG.

In the same vain, Kurtosis is the expected value of the standardized data raised to the fourth power. Kurtosis of a normal distribution is usually 3 . If it is less than 3 , it is said to be platykurtic which implies that the distribution produces fewer and less extreme values than normal distribution. Then, when it is greater than 3 , it is said to be leptokurtic, which means it produces more values than the normal distribution. The implication is that high kurtosis shows that there could be extreme returns (either positive or negative), that is in case of investors. From Table 1 above, all the variables produced less extreme values than normal distribution.

Table 2. Regression result of FAA and RGDP

\begin{tabular}{|c|c|c|c|c|}
\hline \multicolumn{5}{|c|}{ Dependent Variable: RGDP } \\
\hline \multicolumn{5}{|c|}{ Method: Least Squares } \\
\hline \multicolumn{5}{|c|}{ Date: 11/13/18 Time: 03:06 } \\
\hline \multicolumn{5}{|c|}{ Sample: 19812016} \\
\hline \multicolumn{5}{|c|}{ Included observations: 36} \\
\hline Variable & Coefficient & Std. Error & t-Statistic & Prob. \\
\hline LOGFAFG & 2168.108 & 562.9302 & 3.851469 & 0.0005 \\
\hline FASG & -35.46813 & 10.40605 & -3.408413 & 0.0018 \\
\hline FALG & 102.1069 & 19.33774 & 5.280188 & 0.0000 \\
\hline $\mathrm{C}$ & 9504.753 & 2599.628 & 3.656197 & 0.0009 \\
\hline R-squared & 0.948506 & \multicolumn{2}{|c|}{ Mean dependent var } & 31757.15 \\
\hline Adjusted R-squared & 0.943678 & \multicolumn{2}{|c|}{ S.D. dependent var } & 18151.71 \\
\hline S.E. of regression & 4307.809 & \multicolumn{2}{|c|}{ Akaike info criterion } & 19.67869 \\
\hline Sum squared resid & $5.94 \mathrm{E}+08$ & \multicolumn{2}{|c|}{ Schwarz criterion } & 19.85463 \\
\hline Log likelihood & -350.2163 & \multicolumn{2}{|c|}{ Hannan-Quinn criter. } & 19.74010 \\
\hline F-statistic & 196.4758 & \multicolumn{2}{|c|}{ Durbin-Watson stat } & 0.765465 \\
\hline Prob(F-statistic) & 0.000000 & & & \\
\hline
\end{tabular}

Source: Researcher's calculation, 2018 using e-views, version 9.

From Table 2 above, $\mathrm{R}$ is $97.39 \%$ (Square root of $\mathrm{R}^{2}$ ) which signifies that the RGDP and the independent variables (FAFG, FASG and FALG) are highly correlated. There is a strong and positive relationship between RGDP and the Federation Account Allocated Funds (FAAF) utilized by the three tiers of government. The $\mathrm{R}^{2}$ which denotes the coefficient of correlation measures the extent to which independent variables used in this study determine the level of variation in the dependent variable. From Table 2 above, $R^{2}$ is $94.85 \%$ which is the level of variability the FAFG, FASG and FALG can explain in RGDP. That means, $5.15 \%$ can be explained by other factors not accounted for in the model. According to Field (2009) when Durbin-Watson is at one (1), there is no cause for worry. The Durbin-Watson is approximately 1, which means, it is within the limit that does not give cause for concern (Field, 2009). From Table 2 above, F-statistics is 196.4758 with the p-value of 0.0000 which is less than 5\% level of significance. The result also depicts that the model is statistically significant and appropriate for the study. 


\subsection{Test of Hypothesis $\left(\mathrm{Ho}_{1}-\mathrm{H}_{3}\right)$}

Acceptance and rejection of null hypothesis in this study is based on T-Statistics because the research employed multi-regression as the analytical tool. However, $\mathrm{Ho}_{1}-\mathrm{Ho}_{3}$ formulated earlier state that Federation Account Allocated Funds (FAFG, FASG and FALG) do not have significant impact on RGDP. The T-statistics of the individual variables on Table 2 depicts that FAFG and FALG have significant positive impact on RGDP while FASG has significant negative impact on RGDP. The regression results (both positive and negative) are significant. Therefore, Ho1 and Ho3 are hereby rejected, while the alternative which states otherwise accepted. On the contrast, Ho2 is accepted and the alternative rejected.

The result of this study is in agreement with the findings of other scholars like (Usman, 2011; Dagwom, 2013; Ojide \& Ogbodo, 2015) who found that revenue allocation to the Federal and Local Governments impact positively and significantly on the economy. Their various studies also established that revenue allocation to the State Government has significant negative impact on the economy. This could be likened to too much expenditure responsibilities on the part of the state and perhaps mismanagement of resources. However, the finding of this present study is in conflict with the study of Ohiomu and Oluyemi (2017). Their study revealed that revenue allocation to the State Government is contributing $26 \%$ increase on RGDP while that of the Federal Government is $0.001 \%$ while the local government is $-0.03 \%$.

\section{Conclusion and Recommendation}

The findings of this study has provided empirical evidence that utilization of federation account allocated fund by the state governments does not have significant positive impact on economic growth in the country. This is attributed to too much unnecessary spending obligations and misuse of funds at the state level. In addition, the present federally collected revenue sharing formula in Nigeria is not compatible with the prevailing economic situation in the country. Therefore, the study suggests, among others, that revenue sharing formula in the country should be based more on impact of expenditure incurred on executed projects (long term and short term) by each tier of government than on any other parameter to achieve fairness and efficiency in public service delivery at all levels of governance.

\section{Acknowledgements}

This paper is part of the Ph.D. research work of the Author which is sponsored by the Institute of Chartered Accountants of Nigeria (ICAN) through Ph.D. research grant. I sincerely thank Prof. John Uzoma Ihendinihu and Prof. Kabiru Isa Dandago for their relentless follow up and guide that helped to complete the entire Ph.D research work.

\section{References}

Adams, R. A. (2006). Public sector accounting and finance. Lagos, Nigeria: Corporate Publishers Ventures.

Adangor, Z. (2015). The Principle of Derivation and the search for Distributive Justice in the Niger Delta Region of Nigeria: The Journey So Far. Journal of Law, Policy and Globalization, 45, 155-133.

Akanbi, O., \& Du Toit, C. B. (2011). Macro-econometric modelling for the Nigerian Economy: a Growth poverty gap analysis. Journal Economic Modelling, 28, 335-350. https://doi.org/10.1016/j.econmod.2010.08.015

Ani, W. U., \& Obara, L. C (2002). Public Sector Accounting principles and practice. Blueprint Limited, Port Harcourt, Nigeria.

Arowolo, D. (2011). Fiscal federalism in Nigeria: Theory and dimensions. Afro Asian Journal of Social Sciences, 2(22), 1-21.

Arowoshegbe, A. O., Uniamikogbo, E., \& Aigienohuwa, O. O. (2017). Tax Revenue and Economic Growth in Nigeria. Scholars Journal of Economics, Business and Management, 4(10), 696-702.

Ashley, D. (2018). What is economic growth and development? Definition, theories and Indicators.

ATSWA. (2009). Public Sector Accounting. Accounting Technicians Scheme West Africa (ATSWA) (2nd ed.). ABWA Publishers.

Audit Ordinance Act. (1956). The Consolidated Revenue Fund, Contingency Fund \& Development Fund.

Augusto, M. C., Sena, R. E., \& Fontenele, S. (2012). The new endogenous growth theory. An Investigation on growth policy for developing countries. Retrieved August 8, 2017, from www.sober.org.br/palestra/12/070079.pdf

Ayuba, A. J. (2014). Impact of Non-oil tax revenue on economic growth: The Nigerian Perspective. International Journal of Finance and Accounting, 3(5), 303-309. 
Bashir, K. A. (2008). The mechanisms of revenue allocation: understanding the need for effective Data collection and management. Workshop Paper.

Central Bank of Nigeria. (2016). CBN Statistical Bulletin. Abuja, Nigeria.

Constitution of the Federal Republic of Nigeria. (1999). Second Schedule. Part 1: Exclusive List. Part 11: Concurrent Legislative List. Part 111 Supplemental and Interpretation.

Dagwom, Y. D. (2013, July-September). Revenue allocation and economic development in Nigeria: An empirical Study. SAGE Open, 1-7.

Dhanshwar, G. (1997). Private investment and endogenous growth: evidence from Cameroon. IMF working paper. WP/97/165. https://doi.org/10.5089/9781451980004.001

Domar, E. (1946). Capital Expansion, Rate of Growth, and Employment. Econometica, 14(2), 137-147. https://doi.org/10.2307/1905364

Domar, E. (1957). Essays in the theory of economic growth. New York, NY: Oxford University Press.

Fadare, S. O. (2010). Recent banking sector reforms and economic growth in Nigeria. Middle Eastern Finance and Economics, (8).

Faridi, M. Z. (2011). Contribution of Fiscal Decentralization to Economic Growth: Evidence from Pakistan. Pakistan Journal of Social Sciences (PJSS), 31(1), 1-13.

Federation Account Act. (1992 \& 2002). Retrieved November 12, 2018, from www.lawNigeria.com

Field, A. P. (2009). Discovering statistics using SPSS: and sex and drugs and rock 'n' roll (3rd ed.). London: Sage.

Finance (Control \& Management) Act. (1958). Part 11 Consolidated Revenue Fund; Part IV Contingency Fund; Part V Development Fund. Retrieved November 16, 2018, from https://www.lawyard.ng/wp.../

Gemmell, N., Kneller, R., \& Sanz, I. (2013). Fiscal decentralization and economic growth: Spending versus revenue decentralization. Economic Inquiry, 51(4), 1915-1931. https://doi.org/10.1111/j.1465-7295.2012.00508.x

Gordon, R. J. (1996, August 1). The time-varying NAIRU and its implications for economic policy. National Bureau of Economic Research. https://doi.org/10.3386/w5735

Harrod, R. F. (1939). An Essay in Dynamic Theory. The Economic Journal, 49(193), 14-33. https://doi.org/10.2307/2225181

Ihe, N. J., \& Umeaka, E. C. (2006). Public Sector Accounting and Finance (The Nigerian Perspective). Peace Publishers Limited, Owerri, Nigeria.

Ihenyen, C. J., \& Mieseigha, E. G. (2014). Taxation as an instrument of economic growth: The Nigerian Perspective. Information and Knowledge Management, 4(12), 49-53.

Ikeji, C. C. (2011). Politics of Revenue Allocation in Nigeria: A reconsideration of some Contending issues. Sacha Journal of Policy and Strategic Studies, 1(1), 121-136.

Investopedia. (2017). Real Gross Domestic Product (GDP). Investopedia, LLC. Retrieved December 20, 2018, from https://www.investopedia.com/

Jimoh, A. (2011). Revenue formula and public accountability. Retrieved-on-July 17, 2017, from https://abujimoh.wordpress.com

Koutsoyainnis, A. (1977). Theory of econometric. Humpshire Macmillan Education Ltd, London. https://doi.org/10.1007/978-1-349-09546-9

Lukpata, V. I. (2013). Revenue Allocation Formulae in Nigeria: A continuous search. International Journal of Public Administration and Management Research (IJPAMR), 2(1), 32-38.

Market Business News. (2018). What is economic development? Definition and examples. Retrieved November 13, 2018, from https://marketbusinessnews.com/financial-glossary/economic-development/

Micaiah, W. (2015). Nigerian Government Revenue Allocation. Statisence. Retrieved July 31, 2017, from https://www.slideshare.net/statisense/nigerian-government-revenue-allocation

Munir, K., \& Sultan, M. (2016). Are some taxes better for growth in Pakistan? A Time Series Analysis. MPRA. Retrieved from https://mpra.ub.uni-muenchen.de/688281/ 
Musgrave, R., \& Musgrave, P. B. (2004). Public finance in theory and practice (5th ed.). New Delhi, India: Tata McGraw-Hill Education Private Limited.

My Accounting Course. (2017). What is Real GDP?. Retrieved December, 20, 2018, from https://www.myaccountingcourse.com/

National Revenue Mobilization, Allocation and Fiscal Commission. (1992, April 21-23). Revenue Allocation. Notes on the role and activities of the NRMAFC. Presented at the National seminar on Revenue mobilization for states and local governments, Enugu.

Nkoro, E., \& Uko, A. K. (2016). Autoregressive Distributed Lag (ARDL) co-integration technique: Application and interpretation. Journal of Statistical and Econometric Methods, 5(4), 63-91.

Nnamocha, P. N. (2002). Public finance for a developing economy: The Nigerian Application. Bon Publisher Owerri, Imo State, Nigeria.

Odigwe, D. A., \& Aibieyi, S. (2015). Fiscal federalism and development in Nigeria. Public Policy and Administration Research, 5(7), 36-44.

Ohiomu, S., \& Oluyemi, S. A. (2017). Fiscal Federalism and Economic Growth Nexus: Empirical Evidence from Nigeria. International Journal of Economics, Commerce and Management United Kingdom, 5(2), 131-146.

Ojide, M. G., \& Ogbodo, J. C. (2015). Federation Account Allocation in Nigeria: implication for Growth. Journal of Poverty, Investment and Development, 7, 8-11.

Okafor, R. G. (2012). Tax revenue generation and Nigerian economic development. European Journal of Business and Management, 4(19), 49-56.

Oluwasegun, V., \& Anofi, D. (2015). Reps to Buhari: present new revenue allocation formula. The Nations News.

Omodero, C. O., Ekwe, M. C., \& Ihendinihu, J. U. (2018). Derivation funds management and Economic development of Nigeria: evidence from Niger Delta States of Nigeria. International Journal of Financial Research, 9(2), 165-171. https://doi.org/10.5430/ijfr.v9n2p165

Onu, O. (1994). Federal - state fiscal relation. In Eliagwu, I.T. et al, (Eds.), federalism and national Building in Nigeria. Abuja: National Council of Inter-governmental Relations.

Onuigbo, R. A., \& Eme, O. I. (2015). State Governors and Revenue Allocation Formula in Nigeria: A case of the Fourth Republic. International Journal of Accounting Research, 2(7), 14-36. https://doi.org/10.12816/0017348

Orluwene, O. B. (2008). The politics of revenue allocation in Nigeria since Independence: an Overview. Selected Works. Retrieved from http://works.bepress.com/ozyb-orluwene/4/

Pesaran, M. H., Skin, Y., \& Smith, R. J. (2001). Bounds, testing approaches to the analysis of level Relationships. Journal of Applied Econometrics, 16(3), 289-326. https://doi.org/10.1002/jae.616

Prateek, A. (2017). What is economic growth?. Retrieved November 12, 2018, from https://www.intelligenteconomist.com/economic-growth/

Romer, P. M. (1994). The origins of Endogenous Growth. The Journal of Economic Perspectives, 8(1), 3-22.

Sciencedaily. (2018). Economic growth. Retrieved November 12, 2018, from https://www.sciencedaily.com/terms/Economic-growth.htm

Students Pye Nigeria Limited. (1998). Public Sector Accounting and Finance. Published by Students Pye Nigeria Limited, Lagos Nigeria.

Syed, A. R., Yasir, A., \& Farhan, M. (2012). Role of agriculture in economic growth in Pakistan. International Research Journal of Finance and Economics, 83, 180-186.

Tejvan, P. (2018). Economic growth. Retrieved November 13, 2018, from https://www.economicshelp.org

Usman, O. A. (2011). Revenue allocation formula and its impact on economic growth process in Nigeria. Journal of Economics and Sustainable Development, 2(3), 29-37.

Vanguard News Nigeria. (2017, May 22). FG, States, LGs, Share N1.41trn in Q'1 2017.

William, E., \& Serigo, R. (1993). Fiscal policy and economic growth, an empirical investigation. NBER (National bureau of economic research). Working paper (p. 4499). 